\title{
A long history of breakdowns: A historiographical review
}

\section{Dániel Margócsy}

Department of History and Philosophy of Science, University of Cambridge, UK

\begin{abstract}
This introduction to this special issue argues that network breakdowns play an important and unacknowledged role in the shaping and emergence of scientific knowledge. It focuses on transnational scientific networks from the early modern Republic of Letters to 21 st-century globalized science. It attempts to unite the disparate historiography of the early modern Republic of Letters, the literature on $20^{\text {th }}$-century globalization, and the scholarship on Actor-Network Theory. We can perceive two, seemingly contradictory changes to scientific networks over the past four hundred years. At the level of individuals, networks have become increasing fragile, as developments in communication and transportation technologies, and emergence of regimes of standardization and instrumentation have made it easier both to create new constellations of people and materials, and to replace and rearrange them. But at the level of institutions, collaborations have become much more extensive and long-lived, with single projects routinely outlasting even the arc of a full scientific career. In the modern world, the strength of institutions and macro-networks often relies on ideological regimes of standardization and instrumentation that can flexibly replace elements and individuals at will.
\end{abstract}

\section{Keywords}

scientific networks, network breakdowns, transnational science, modernization

\section{Correspondence:}

Dániel Margócsy, Department of History and Philosophy of Science, University of Cambridge, Free School Lane, Cambridge UK, CB2 3RH

Email: margocsy@gmail.com 
What happens when scientific networks break down? If the Catholic Church condemns you to house arrest in Florence, how can you, Galileo, manage to remain in touch with your scholarly contacts locally, in Rome, and abroad (Findlen and Marcus, 2017)? Or, if you are a 21st-century lab scientist, and your collaborative project falls apart over the interpretation of your results, how do you recalibrate the work of your research team, find new partners, and branch into new directions (Lakoff, 2017)? This special issue seeks answers to these questions, and investigates the nature and consequences of network breakdowns across history, from the early moder period to today. This introductory article offers a highly selective review of the current historiography on scientific networks, with a special focus on their disappearance and transformation in the face of natural, personal, social and political adversities. In reviewing this historiography, I especially focus on three major questions. What material and social factors may cause networks to fall apart? Does the dissolution of scientific networks have negative or positive effects on the production of knowledge? How do long-term historical developments influence the causes and effects of network breakdowns? To answer these questions, I make a number of brief theoretical points and provide the preliminary sketch of a historical framework for dealing with failures and disappearances.

There are various kinds of networks. A network can be constituted by a small group of people tied together in a project, such as members of a laboratory or editors of a journal. A network can be a well-defined, large-scale project, organization or institution that connects people across continents and generations. A number of people connected through weak ties who do not necessarily share common goals, participate in the same project, or work in the same organization, can also make up a network; indeed, as Milgram (1967) has shown, the whole of humanity can be understood to form one network, connected through weak ties with six degrees of separation. And, as ActorNetwork Theory (ANT) describes, humans and non-humans form alliances and networks to ensure their survival and achieve their goals (Latour, 2005; Law and Hassard, 1999). In this latest iteration, the network is not only one of the many features of the world around us, but is the foundational element. This paper and the special issue take a broad view of networks, including such cognates as assemblage, commons or rhizome (Deleuze 
and Guattari, 2004, Ong and Collier, 2005). They discuss a variety of networks with strong and weak ties, with human and non-human actors, but they do not necessarily commit themselves to the ontological primacy of networks. As Biagioli (2017) reminds us in this issue, networks are not the only explanatory framework available for understanding and interpreting how science works. They are no more than a helpful analytical tool, and work best when paired together with concepts such as commons, institutions, humans, instruments or things. For how else could networks break down and disappear, if there weren't other things to replace them? Latour (2013), too, acknowledges the ontological poverty of ANT, and proposes complementary explanatory schemas.

\section{From growth to rupture}

Science and Technology Studies (STS) tends to focus on beginnings and growth. From the early Sociology of Scientific Knowledge to recent works on the circulation of knowledge, scholars have investigated in detail how scientific networks are established and spread, and scrutinized how consensus is reached, so that local knowledge turns global and universal (Collins, 1985, Galison, 1987). Much of this literature has focused on the formation of scientific consensus, and its debates have centered on the question whether natural or social factors are responsible for reaching agreement. Arguably, scholars in STS have been interested in the formation of networks (and/or consensus) because they share the belief that, by and large, scientific knowledge ultimately does appear to become universal as it spreads along networks, even if only for socio-political reasons (for qualifications, see Tsing, 2005).

The recent literature on the circulation of knowledge is often fueled by a similar concern about how local knowledge spreads across cultural, political and temporal boundaries (Anderson, 2008; Cook, 2007; Raj, 2007). As Secord (2004) has argued, 'the

spread of knowledge, its global ubiquity and circulation,' is the major question of history of science in the new millennium, and, for most historians, the answer to this question seems to be transnational networks (Herran et al., 2012). Moreover, even when critical of the mainstream globalization literature, historians and STS scholars tend to accept its 


\section{A Long History of Breakdowns}

major tenet that the modern world and modern science are characterized by increasing connectivity, the fast sharing of information, and the global, often irreversible spread of knowledge (e.g. Jasanoff and Martello, 2004; for historians' similar fascination with networks, see Bell, 2013). Although historians of science are wary of whiggish narratives, they have no problems with equating the growth of networks with historical success. Latour's Actor-Network Theory, for example, explains success through the growth of networks. While some of Latour's work (e.g. Aramis, Latour, 1996) is more ambiguous about the possibility of distinguishing between network successes and apparent failures, the classical formulation of ANT argues that both human and nonhuman agents form alliances to win and survive, and the success of scientific theory (or, indeed, anything else), is simply explained by the number of allies an agent can enlist. The Pasteurization of France explained Pasteur's cultic status by detailing how he was able to manipulate an army of minions (Latour, 1993).

Yet endings are just as important as beginnings. As Strathern (1996) has argued in response to Latour's version of ANT, one needs to cut the network to make it succeed as a distinct entity. Networks gain identity by the boundaries they establish. Without boundaries, networks could grow unchecked and, if the bigger network always wins, just one network would eventually encompass the whole world, a world in which separate identities and distinctive features are dissolved. Philosophically speaking, it is only by setting limits to network growth that one can differentiate between different entities or identities. Otherwise, we would end up blackboxing the whole world.

Strathern claims convincingly that it is precisely the imperfect and temporary nature of alliances that gives networks power, shape and a distinct identity. Translated into STS, Strathern's argument suggests that scientific communities are not eternal or omnipresent. The development of science is not necessarily the result of a growth of networks. It is not the ever-growing accumulation of previously acquired knowledge along the same network. The acquisition of human and non-human allies, the growth of impressive citation counts, and the development of the largest correspondence network are not the only strategies and markers of achieving scientific success. Sometimes, it is necessary to limit and even break networks both to determine a field's identity and to achieve breakthroughs. In this respect, Strathern's work on identity formation finds 


\section{A Long History of Breakdowns}

resonance with studies of demarcation, which examine how science is distinguished from pseudoscience in everyday life, and how disciplinary boundaries are established within science (Lamont and Molnar 2002; Laudan, 1983; Popper, 2005). While it is clear that there is no clear-cut philosophical and methodological difference between science and pseudoscience, the sociological and rhetorical importance of such demarcations is beyond dispute (Fuller, 1991; Gieryn, 1999; Gordin, 2012). As Biagioli (1990) has shown, Galileo's conscious decision to break with the Aristotelian terminology of the Jesuits, which he pretended not even to understand, helped him establish the identity of his own research paradigm. Similarly, as Vedel and Irwin argue, it is by the constant alignment, unalignment, and realignment of professional interests and identities that academics and industry scientists are able to successfully collaborate and break collaborations as dictated by their own interests (Vedel and Irwin, 2017).

A study of breakdowns takes a step beyond demarcation. Historians have shown convincingly how the delimitation of scientific networks does not result in a total destruction of communications across boundaries. While limits help shape a network's identity, they often remain porous and do not break all types of contact (for a similar analysis of the 'pollution of the commons' in this issue, see Biagioli, 2017). The establishment of disciplinary boundaries might still facilitate communication amongst networks through 'boundary objects', and feisty scholarly duels between opposing camps still yield citation counts for one's opponents (Star and Griesemer, 1989). As it happens, scientific debate and the vocal ostracization of anti-scientific propaganda do not necessarily result in the annihilation or the weakening of the other side. Recent research shows, for example, that vaccination campaigns that debunk anti-vaccination myths do not lead to higher vaccination rates, even when the public appears to be swayed by the argument of the campaigners (Nyhan et al., 2014). The historiography has examined in much less detail how total radio silence might be a more effective strategy in breaking alliances, severing contacts and establishing new fields. Stalinist politics, for example, first attacked its enemies by putting them on the stage of court trials, and then, once they were disappeared, their names were completely dropped from circulation (Lukács, 1962).

It is important to emphasize that, as in the case of Stalinist Soviet Union, the severance of contacts does not happen naturally and inevitably. In many cases, powerful 


\section{A Long History of Breakdowns}

material, social and political forces are required to stop the circulation of information, people, and material objects, and to fragment and reshape scientific consensus. While loose networks between distant and badly connected groups might dissolve with relative ease when a few go-betweens disappear, more tightly-knit organizations, with strong and numerous ties between the members, have much more staying power. As Merton (1968) has argued, bureaucratic organizations can often become behemoths that are hard to disrupt, or to bring into new directions. Similarly, once established, flows of knowledge tend to have some inertia, and explicit, 'disruptive' pressure is needed to stop them or to redirect them into new directions (Christensen, 1997).

Indeed, while the current emphasis on the emergence and growth of networks suggests a picture of the development of science as cumulative growth, a focus on network breakdowns reveals a more nuanced picture of the haphazard, fluctuating nature of scientific change, punctuated by discontinuities such as Foucauldian epistemic shifts or Kuhnian paradigm shifts (Foucault, 1970; Kuhn, 1962). Few scholars apply Kuhn's ideas of paradigm change in their historical research these days, and most believe that change happens in a piecemeal process (Biagioli, 2012). Yet scientific consensus is constantly in flux, driven to and fro by changing material conditions and social, commercial and political pressures, where different kinds of knowledge are rejected and others accepted at different times. As science develops, some professional communities gain ascendancy for a decade or two, while others lose importance for a while, only to regain it again. Translating Kuhn into sociological terms (something Kuhn himself would not have necessarily embraced), we can argue that at the juncture of paradigm change, some scientific networks break down, while others emerge. As Keller (1983) shows incisively, for example, the geneticist Barbara McClintock was able to carve out new paths for science because her sex and maverick personality alienated her from the mainstream of biochemical research in genetics in the 1940s (but see Comfort, 2003). She was only connected to a few scholars, closeted off with her close collaborators in Cold Spring Harbor, and the majority of scholars in modern genetics (her larger scholarly network) dismissed her ideas. While these features had high personal costs for McClintock, they ultimately contributed to a highly original and successful research paradigm that was vindicated in the 1970s (for similar examples, see Davis, 1997; Schiebinger, 2004). 


\section{Breaking networks, producing knowledge}

Ruptures in social networks play an important role not only in the process of establishing disciplinary and scientific identities. They can catalyze the production of knowledge as they help scientists cope with the natural limitations of human life. Networking is timeconsuming and, while it has beneficial effects because of knowledge spillovers, it might also take a researcher away from other work. As scholars well know, well-networked scientists often have little time to perform research, and instead spend their time preparing research grants and supervising postdocs. While research indicates that, in general, increased collaborations lead to publication productivity, Lee and Bozeman (2005) have shown that this is not a direct, linear correlation. First of all, there is a limit to the number of collaborators with whom a scientist can productively engage. In their sample, Lee and Bozeman found no scientist who worked with more than 43 collaborators during a twelve-month period. Even Pál Erdős, the most collaborative mathematician of all times, had only 511 co-authors during his eccentric life, and was able to achieve this only by breaking with the traditional kinship networks of marriage and sedentarism (Erdős Number Project, 2014). Moreover, especially in developing countries where there are high transactions costs to setting up collaborations, an increase in the size of one's professional network does not necessarily increase productivity (Duque et al., 2005; Sooryamoorthy and Shrum, 2007; but see Sooryamoorthy, 2014). Perhaps, networking skills and analytical ability could even be negatively correlated at one level. This was one of the reasons why René Descartes decided to selectively withdraw from contemporary networks of correspondence. To establish himself as the modern philosopher, and to have enough time to do research, he decided to isolate himself from other, competing versions of reforming scholastic thinking. Exasperated by Thomas Hobbes' shoddy mathematics and unpleasant metaphysics, Descartes quickly decided to break his correspondence with the English philosopher, writing that he 'did not take ... his writings seriously enough to think that I was obliged to spend my time refuting it' (Malcolm, 1994: I/118). If life is finite, one's networks must be finite, too. 


\section{A Long History of Breakdowns}

Not all productive network ruptures are the result of a scientist's strategic career management. External factors, such as war, natural catastrophes and instrument failures can also result in breakdowns of scientific networks, and yet can have a catalytic effect on the development of knowledge. As Erich Auerbach (1957: 496) claimed at the end of Mimesis, he was only able to finish his masterpiece because of World War II. Separated from his beloved books in what he perceived to be provincial Istanbul, he was finally able to sit down and write up his ideas in a groundbreaking volume. Like military conflict, natural and human-made disasters can also disrupt existing collaborations, and then sprout new technoscientific networks. For example, the technopolitical explosion of Chernobyl quickly pulled together medical professionals from Moscow to Los Angeles, who all sought to profit from the experience of treating patients exposed to high levels of radiation; then, as interest in the patients faded, these collaborations quickly disbanded, leaving the patients to their fate in post-Chernobyl, post-socialist Ukraine and Belarus (Petryna, 2003). One could observe similar phenomena in the case of the gas leak incident of Bhopal, one of the worst industrial tragedies in history. As Fortun (2001: ix) has claimed in her study, the 'Bhopal disaster has brought many different people together, for many different kinds of collaborative work', locking victims, legal advisors, aid organizations, industry representatives and politicians in a bind. While disasters and political conflicts disrupt existing networks, they can also contribute to the formation of new constellations of knowledge production, although, given the circumstances, one might well wish that such new knowledge had never been produced.

At the level of everyday life, sociologists and philosophers of science have made it abundantly clear that material breakdowns are absolutely necessary for the production of knowledge or the shaping of scientific research. In terms of experimental systems, composed of assemblages of humans, instruments, protocols and data, science progresses precisely by the unexpected twists and turns of experimental findings: The emergence of knowledge is conditional on the iterative rupture of différance between the researchers' expected and acquired results (Rheinberger, 1992). For large scientific instruments such as the Hubble telescope, it is the default to be in a state of disrepair, and projects to rectify their breakdowns bring forward much new knowledge about how those instruments, the operators of the instruments, and the whole universe work (Schaffer, 
2011). As these cases reveal, breakdowns bring forward new constellations and networks of knowledge production. Yet it would be a mistake to reduce such network ruptures to the simple, flexible rearrangement of constitutive elements. When the Iron Curtain disrupted and limited the pre-War technological cooperation between Western and Eastern Europe (Mehilli, 2014; Vargha, 2014), when the grandmothers of the Argentinian disappeared lost control of the DNA identification techiques they helped develop (Smith, 2017), some things got irredeemably lost, for better or worse. And if studies of networks continue to focus on emergence, resilience and flexibility, they will fail to account for the loss involved in such scenarios.

\section{The historical problem: Changing network ecologies}

If network failures are not mere blips in the progress of history, we need to attend to their functioning. We need to understand how different networks are vulnerable to different types of breakdowns, social and material. We need to understand how breakdowns might bring down scientific research, but can also serve to reconstitute it. We need to understand that there is a history to breakdowns, and to develop a typology that could help us understand how different kinds of networks exhibit proneness to different kinds of failures. ${ }^{1}$ In the rest of this paper, I examine the different breakdown patterns of projects pursued in loose networks, dominated by one actor and tied by weak links, and of tightly connected, targeted research collaborations, often done in institutions or formal organizations. As I argue, scientific networks end for highly different reasons in these two different constellations of knowledge production. The research projects of loosely connected scholarly networks tend to dissolve with the death of the key human actors. Tightly connected collaborative research projects, in contrast, do not disappear with the deaths of humans, but when the political or bureaucratic ideology governing them collapses. While my primary aim is to highlight the diverging patterns of rupture in two different network ecologies, I also make a subsidiary, chronological claim. I contend that, by and large, loosely connected networks dominated the scientific research of the early modern period, while long-term collaborative projects became typical for science only from the end of the eighteenth century onwards. 


\section{Early modern networks}

In recent years, historians have come to agree that networks dominated early modern science. Some have argued that this period was remarkable because of the Republic of Letters, a strikingly homogenous network consisting almost entirely of European male scholars (Daston, 1991; Goldgar, 1995; Goodman, 1996; Habermas, 1991). Others have emphasized, instead, that modern science emerged from the global interaction of European artisans, African slaves, Muslim ulamas and Chinese traders, a highly heterogeous network (Raj, 2007; Roberts, 2011; Schiebinger, 2004; Schiebinger and Swan, 2005). Despite these differences, I would suggest, both the Republic of Letters and the heterogenous, global networks of the early modern period were loosely-knit networks organized around individual people, and they dissolved when those individuals died. While the Republic of Letters as an organizing concept - under the ethos of disinterested scholarly research - may have united scholars across centuries, it did not result in longterm, structured, tightly-knit collaborations around a commonly shared goal. While early modern globalization might have resulted in multi-generational trading networks that survived for centuries, such as the Dutch or the English East India Companies, these institutions did not foster focused scientific research on a particular problem for long decades, with the potential exception of navigational science (Huigen et al., 2010). They only facilitated the circulation of knowledge through weak ties and across geopolitical boundaries, without formulating a coherent long-term science policy (Harris, 1996; Lux and Cook, 1998). As the recent literature on go-betweens has shown, most concentrated knowledge exchanges survived only as long as a particular agent, such as Edward Bancroft or James Dinwiddie, was active and present on a site (Schaffer et al., 2009). As Findlen and Marcus' (2017) article in this issue exemplifies, it makes perfect sense for early modern studies to understand the growth, fluctuation and dispersion of networks as conditioned by the actions and lifespan of one charismatic figure, such as Galileo.

Most scholars agree that, with the exception of scientific academies, the networks of the Republic of Letters were characterized by weak ties. Grafton (2009: 10) writes that this institution aimed to cross 'political, linguistic and religious borders', or, to quote 


\section{A Long History of Breakdowns}

Waquet (1989: 490), it gave a 'sense of unity and solidarity to the learned'. In this world, scientific activities were often organized around the interests of individual human actors, rather than around bureaucratic techniques or communitarian ideologies. It is very difficult to find a sustained, collaborative scientific project in the early modern period that was designed to last beyond the founders' lifetime. Individual figures were responsible for running even the largest scientific projects in the period, such as Buffon's Natural History or Diderot's Encyclopédie, and were finished either at death or even earlier. In the field of the physical sciences, no $17^{\text {th }}$ - or $18^{\text {th }}$-century astronomer developed an observational standard that could unite generations of astronomers, as it would happen with the Carte du ciel a few centuries later. Tycho Brahe's observatory in Uraniborg famously collapsed when the aristocrat fell out of royal favor, and his collaborative project of the observation of the heavens was not continued after his death (Thoren, 1990; Mosley, 2007). Other disciplines were no different. When early modern natural history experienced an information overload with the exponential growth of the number of known plant species, one would think natural historians might have devised a collaborative, multi-generational project for surveying and classifying all species. Yet this did not happen, and instead individual scholars took up the burden of establishing a classificatory system for all species. Take, for example, the case of the Oxford botanist James Sherard, who decided to survey the whole of botanical literature on his own, and began to write a comprehensive dictionary and encyclopedia of the plant world, which stopped only when death intervened. His successor, Johann Jacob Dillenius was similarly optimistic, but he too died before completing the manuscript, which languishes in the Bodleian today (Margocsy, 2010). Similarly, while during his lifetime Linnaeus was able to enlist an impressive number of his students (the apostles of Linnaeus) to collect information for him during their travels in the global pursuit for botanical knowledge, this network quickly dissolved with the Swedish master's death in 1778 (Sörlin, 2008). While individual manuscripts might have survived the deaths of their authors (e.g. the posthumous, 1630s publication of the Insectorum sive minimorum animalium historia of Thomas Moffett, based on the notes of Conrad Gesner from a century before), the latterday editors of these publications hardly ever observed the intentions and methodologies

of the original author (Neri, 2011). ${ }^{2}$ Even in the field of ecclesiastical history, a highly 


\section{A Long History of Breakdowns}

collaborative discipline strongly supported by the churches of Europe, most projects were limited to the lifetime of one scholar. No church historian intentionally set up a scholarly project that would span several generations, although it was eminently clear that church history was a massive enterprise. Even Jean Bolland originally thought that his Acta sanctorum could be completed during his own lifetime, though, in reality, the project would not be finished until 1940 (Knowles, 1958).

Arguably, the scientific academies and societies that began to emerge in the 17th century were held together by strong ties, and not only weak links, and some scholars have argued that it was precisely these stable institutions that heralded the dawn of modern science (David, 2005; McClellan, 1985). The French Académie des sciences, the Accademia del Cimento, and even the Royal Society were hierarchical organizations that did not exude the spirit of democratic egalitarianism, as the Republic of Letters did. Yet these organizations did not usually foster an institutional culture of long-term, collaborative research. First of all, many academies survived only for a generation, and ceased activities after a few decades. The Accademia del Cimento, for example, was the plaything of Prince Leopoldo de' Medici, and dissolved only ten years after its foundation, when two of its key members left the court for better paying jobs (Knowles Middleton, 1971: 309-330). Similarly, the Frankfurt Society for Learning ended its activities only fourteen years after its founding, when members' interest petered out. ${ }^{3}$ While the Royal Society has survived to this day, each early president led its research into distinctly new directions, and the personal interests of its secretaries determined the contours of its correspondence network (Miller, 1998; Rusnock, 1999). Things began to change slowly when the cameralist state expressed an interest in enrolling scientific academies and other institutions in its service, although even then most academy projects lasted at most a decade. These developments first occurred in the late eighteenth century, when the Spanish empire launched a series of coordinated botanical expeditions to explore the flora of its colonies. The united visual epistemology of this project was designed precisely to maintain a standard method of observation across a large number of expeditions, even when individual scientists died and the royal administration had changed (Bleichmar, 2012). ${ }^{4}$ The rule of humans was replaced by standardized material and visual technologies. 
If humans were the key component of early modern networks, they were also their major and crucial vulnerability. Of course, the early modern period was an era of limited and failing communications, which resulted in minor breakdowns. Letters did not get delivered, ships carrying specimens sank, and instruments repeatedly failed, but people were equipped to deal with such eventualities, and such failures did not destroy collaborative enterprises. Living in Poland, for instance, the Dutch-German naturalist Johann Philip Breyne knew that he would occasionaly have to wait for two or three years before his correspondents abroad got back to him. This did not bother him overly, he was only worried that such a lack of response indicated the passing of his distant friends. When his friend and patron Hans Sloane was close to dying in London, Breyne made every effort to ensure that his last and concluding letter safely reached the English collector, providing a closure to his exchanges with the correspondent who opened up the networks of England to him. ${ }^{5}$ While one could always resend a letter, and perform a new measurement if an instrument failed, there was no established method to replace a human correspondent. Death put an end to communication and to scientific collaborations.

\section{The world of modernity}

If the early modern world of science was marked by the establishment of loose ties between independently active researchers, which broke down at the moment of death, many modern technoscientific networks are marked by collectivization. The long nineteenth century saw the emergence of long-term international research collaborations, the establishment of corporate research, and state-sponsored big science (e.g. Rankin, 2017). These were much more tightly organized and often institutionalized networks, designed with the express aim of lasting well beyond the lifespan of a single scientist. The reason for the emergence of such long-term networks was partly due to the changing fate of political economics. Early modern sovereigns were frequently entertained by their courtly scientists, such as the Medici pet Galileo, but it was only in the nineteenth century that political leaders and economic corporations began to invest in science as a means of improving their economic performance in the long run. Yet states, corporations or scientific organizations could only design long-term projects if they agreed that scientific 


\section{A Long History of Breakdowns}

networks no longer needed to be maintained by the charisma of an individual luminary like Newton or a laborious networker like Oldenburg. One had to have a strong belief in the power of material and paper technologies to maintain long-term, long-distance scientific research, or, alternatively, in a communitarian society where a shared ideology could unite scientists across generations. In the long-term scientific projects of modernity, there was a shared belief that any individual scientist could be replaced by another equally competent one, because the mainstays of these networks were standardized instruments, bureaucracies and ideologies. The emergence of these networks did not result in the disappearance of the earlier, individual-centered, small-scale projects, which still pepper the landscape of science. The $21^{\text {st }}$-century funding system actually favors the formation of short-term collaborations that dissolve at the end of each grant cycle (for examples of such short-term collaborations, see Lakoff, 2017; Biagioli, 2017). Nonetheless, long-term planning for scientific projects is now a possibility, which was not the case in the early modern era's loosely knit networks.

The historiography has dissected in great detail how modern nation states and commercial organizations developed a growing interest in scientific research. While the Republic of Letters scholarship has emphasized how scholarly networks spread across religious and political boundaries, the historians of $20^{\text {th }}$-century technoscience instead focus precisely on how international politics, nation states and capitalism shape the emergence of networks (Jasanoff and Martello, 2004; Krige and Barth, 2006; Petryna et al., 2006). Modern states and companies provide financial and logistic support for the long-term maintenance of scientific networks. As historians have argued, such networks then collapse together with the change of a political order. For example, political pressures played an important role in the replacement of the International Association of Academies by the pro-Allied International Research Council during World War I (Kevles, 1971). Networks collapse with regime changes in the political and economic world order. As Herran et al. (2012) argue, 'special geopolitical factors' can help us understand 'the role of science in the administration of global affairs', or, as Ong and Collier (2005) claim, late $20^{\text {th }}$-century science can be described as a 'global assemblage', where neoliberalism and global politics shape together how science is practiced and gains a universal reach. In recent years, scholars of the transnational politics of science have 


\section{A Long History of Breakdowns}

focused especially on the global Cold War, while critics of the neoliberal economic regime have paid most attention to the emergence of the global commerce of knowledge from the 1980s, offering the slightly exaggerated impression that, with the end of the Cold War, the political networks of science were simply replaced by the globalization of trade (Hayden, 2003; Hecht, 2011; Lakoff, 2005; Petryna, 2009).

Yet the emphasis on politics and economics does not fully explain the transformation of scientific networks in the nineteenth and twentieth centuries, and why the collapse of scientific networks does not fully coincide with the change of political and economic regimes. Long-term (and long-distance) scientific networks could only emerge when the personality of the scientist ceased to be the primary driver of a network. The nineteenth century saw the emergence of two different discourses and associated material practices that provided a modus operandi for long-term networks. The charisma of the scientist could be replaced by a belief that mechanized protocols, paper technologies, and standardized instruments would sustain the coherence and unity of a scientific network. In addition, the personality of the scientist could also be replaced by faith in a concertedly acting community of scientists united in the search for a better society. Mechanization, communism or a combination of the two could replace the Republic of Letters.

The development of large-scale scientific projects, such as the Carte $d u$ Ciel or the Internationale Gradmessung was made possible by the advent of mechanical objectivity (Daston and Galison, 2008). Extensive scientific networks and institutions, such as the observatory, replaced the master scientist at the helm with instruments and algorithms that were carefully calibrated to withstand the personal idiosyncrasies of everchanging users (Aubin et al., 2010, Lamy 2007). The multi-generational project of the Carte $d u$ Ciel could only survive because of the precise coordination of its members. Although its initiators expected that they would be able to map the coordinates of the starry sky within six or eight years, they soon realized that the project would run much longer. As a result, they began to pay special attention to the network's 'coordination and homogeneity', so as to ensure its success in the long run (Lamy, 2008: 46). Alder (1998) has shown similarly that the late-eighteenth century French military state (a pre-cursor of $19^{\text {th }}$-century developments) could devise pre-Fordist mass manufacturing networks because it developed a system of standardization that could produce functionally 


\section{A Long History of Breakdowns}

equivalent elements while tolerating for individual discrepancies. Human contributors to scientific networks became replaceable elements, coordinated by the standardization of observational and experimental techniques. In early modern networks, the periodic failures of postal systems could be tolerated by maintaining the illusion that charismatic people were at the real center of scientific networks. With the coming of modernity, the failure and death of people could be tolerated by maintaining the illusion of perfect mechanical rules. Networks died when instrumental regimes underwent a change.

Yet mechanization was not the only way to develop long-term, concerted collaboration of humans, instruments and data. In the early nineteenth-century traveler and polymath Alexander von Humbolt's vision, instruments and humans both willingly agreed to participate as morally free citizens of the same polity (Tresch, 2010).

Humboldt's instrumental republic was part of the larger, nineteenth-century societal transformation that resulted in the emergence of nationalism and communism, two highly problematic utopias of the individual's subsumption under a type of imagined community (Anderson, 1991; Tresch, 2012; see also Mrazek, 2002). Science was an important part of both nationalist and communist projects. Lipkowitz (2014) has claimed that the French Revolution, and especially the Napoleonic era, put an end to the international Republic of Letters, laying the foundations of a French national community of science, which, at least until the Battle of Borodino, promised to unite all the scientific practitioners of Europe under one national flag (Lipkowitz, 2014). The nineteenth century saw the proliferation of national scientific languages, fragmenting the united world of Latinity into enclaves carefully patrolled by translators (Gordin, 2015; Waquet, 1998). Geological surveys are prime examples of national, state or empire-driven projects that subsumed a large number of scientists into single coordinated scientific projects; these surveys often lasted decades, as in the case of the Geologische Reichsanstalt in Vienna, or even longer, as in the case of the Geological Survey of Great Britain (Klemun, 2012; Knell, 2007).

While thoroughly opposed to the ideological thrust of nationalism, nineteenthand twentieth-century communism similarly embraced the suppression of the individual scientist within a larger society, this time under the flag of a class-conscious internationalism. This was not just pure ideology, at least when it came to science, but also a pragmatic program of developing large-scale and long-term collaborative 


\section{A Long History of Breakdowns}

enterprises. As Graham and Dezhina (2008: 1) have claimed, 'Soviet science and technology were organized in larger units than found elsewhere, and under the control of fewer influential individuals.' The planned economy required a science also carefully planned. In the field of communist engineering, some large-scale projects were finished in an extremely short time span, such as the White Sea Canal, but others were designed to be developed over a long period of time. The Sibaral project famously ran for over fifty years, with the express aim of redirecting Siberian rivers to irrigate the dry lands of Central Asia. The scientific institutes established in the aftermath of the Bolshevik revolution could survive and maintain the same research program for long decades; the Vavilov State Optical Institute (established in 1918) still sees its history as one of continuous and unbroken development along stable and well-defined research axes (Gogolev and Gan, 2007; Kojevnikov, 2002). Similarly, the new academic city of Akademgorodok, established in the 1950s to promote Soviet science in Siberia, survives to this day as a hotbed of Russian high tech (Josephson, 1997).

Just as in the world of mechanical objectivity, communist and nationalist networks did not break down with the death of an individual. For what was communism itself, if not a long-term project of societal engineering, to be achieved through major individual sacrifices only in the farthest future? As NKVD leader Nikolai Yezhov famously claimed (before he himself was executed), 'when you cut down the forest, the woodchips fly'; every individual could be replaced as long as the network was maintained (Medvedev, 1989: 603). While mechanical objectivity could function through standardization, bureaucracy and paper technologies, the longevity of communist networks was ensured by a mixture of shared ideology and totalitarian surveillance. These networks were reconfigured with each shift in communist ideology, and collapsed with the political and ideological crash of the Soviet system. As Stalinism took newer and newer turns from the 1920s to the 1950s, the networks of avant-garde art, ethnography, biology and linguistics were reshaped again and again, with ostracized scientists executed or sent to the Gulag (Groys, 1992; Slezkine, 1991). It was not deaths that broke networks down. Rather, it was the ideological transformations of scientific networks that caused deaths. 
The complex interaction of mechanized regimes of instrumentation, ideologies of communitarianism, and the modern political-economical system explains why, even in modernity, network breakdowns do not simply align with military interventions and the collapse of the state. Wars have had an obviously large impact on the functioning of scientific networks (indeed, their impact has been much bigger than in the era of the Republic of Letters,), yet they did not always radically reshape or destroy existing scientific networks. The Carte $\mathrm{du}$ Ciel project survived both world wars, and ended only in the 1970s, when its observational and instrumentational regime became outdated. For nationalist and communist scientific networks, one needed the collapse of both state and ideology to stop functioning. Thus the project of German science did not suffer a major blow with the end of World War I, although took several years until it could again fully participate in international collaborations (Windsor, 2014). While Kaiser Wilhelm was sent to exile in the Netherlands, the Kaiser Wilhelm Society's institutes survived and were not even renamed during the Weimar Republic (Macrakis, 1993). In contrast, the end of World War II signaled both the end of Nazi ideology and the German state. While, as many were to bemoan, Nazi scientists were quickly rehabilitated in the West with the rising threat of the Cold War, their scientific projects were nonetheless thoroughly altered. Eugenics became a thoroughly discredited idea, and Konrad Lorenz, for instance, had to refashion his scientific persona, abandoning his earlier project of racial purification (Burkhardt, 2005). Similarly, it was the ideological (and not only the political) collapse of the Soviet project that resulted in the breakdown of Soviet scientific networks. State funding for science dropped radically in the 1990s, the elite situation and reputation of scientists suffered a severe blow and, as a result, many scientists emigrated to the West, exchanging the isolated networks of the Eastern bloc for the globalized world of transnational science.

\section{Conclusion.}

Deaths of people, changing regimes of instrumentation, and the collapse of ideologies. This brief essay has offered accounts of how different networks have different vulnerabilities: early modern loose networks crashed with the death of the individual 


\section{A Long History of Breakdowns}

people at their centers, while modern, long-term, well-defined collaborative projects disappeared with the changing regimes of mechanical instrumentation or the shifting ideologies of the collective. Clearly, while studies of networks focus on formal characteristics, applying the same principles to study humans, viruses and bits, it is equally important to investigate qualitatively how humans, instruments and ideologies interact in the creation and destruction of networks. In some contexts, killing the human destroys the network, but in different contexts, one needs to attack the instrument, or the ideologies behind it, to create new constellations for the production of knowledge.

Equally importantly, a focus on network breakdowns has the potential to offer a counter-narrative to whiggish narratives of the progress of science. Instead of examining the emergence of networks, and how they come to encompass larger and larger segments of global society, it is time to realize how frequently they contract, dissolve and fail to maintain themselves. An attention to such ruptures, whether occasioned by the French Revolution, outdated instrumental apparatuses or the death of a genius, shows how natural knowledge develops by twists and turns, throwing up new paradigms in a punctuated fashion. To every story of emergence, one can find a counter-narrative of dissolution and failure. Sometimes, the only way to recalibrate science is by breaking the networks that sustain it. And this is not always a bad thing, indeed.

\section{Acknowledgments}

This special issue arose from the Breaking Scientific Networks conference held at the Center for Science and Innovation Studies, University of California - Davis, and the editors are very thankful for the financial, intellectual and logistical support of the University of California - Davis, the Center's staff, and especially Mario Biagioli, Aaron T. Norton and Nicole B. Kramer. The author of this article wishes to thank audiences at the Breaking Scientific Networks conference, and at the Sustainable Networks conference at Nanyang Technological University. Michael Bycroft, David Fairer, Paula Findlen, Rebecca Lemov and Elise Lipkowitz offered helpful comments on this project and directed me towards unknown sources. Mark Somos and Bill Rankin have read and commented on various drafts of the paper. This paper was written while the author was a 
visiting fellow at the Max Planck Institute for the History of Science, I am thankful to Sven Dupré for his invitation.

\section{References}

Alder K (1998) Making things the same: Representation, tolerance and the end of the Ancien Regime in France. Social Studies of Science 28(4): 499-545.

Anderson B (1991) Imagined communities: Reflections on the origin and spread of nationalism. London: Verso.

Anderson W (2008) The collectors of lost souls: Turning kuru scientists into whitemen. Baltimore: Johns Hopkins University Press.

Aubin D, Bigg C, and Sibum HO (2010). Introduction: Observatory techniques in nineteenth-century science and society. In: Aubin D, Bigg C. and Sibum HO. The heavens on Earth: Observatories and astronomy in the Nineteenth Century. Durham: Duke University Press: pp. 1-32.

Auerbach E (1957) Mimesis: The representation of reality in western literature. New York: Doubleday.

Barabási AL (2002a) Evolution of the social network of scientific collaborations. Physica A 311: 590-614

Barabási AL (2002b) Linked: The new science of networks. Cambridge: Perseus Books.

Bell D (2013) This is what happens when historians overuse the idea of the network. The New Republic, 7 Oct.

Biagioli M (1990) The anthropology of incommensurability. Studies in History and Philosophy of Science A 21(2): 183-209.

Biagioli M (2012) Productive illusions: Kuhn's Structure as a recruitment tool. Historical Studies in the Natural Sciences 42(5): 479-484.

Biagioli M (2017) Local commons v networked commons. Social Studies of Science. 
Bleichmar D (2012) Visible empire: Botanical expeditions and visual culture in the Hispanic Enlightenment. Chicago: University of Chicago Press.

Burkhardt RW, Jr. (2005) Patterns of behavior: Konrad Lorenz, Niko Tinbergen, and the founding of ethology. Chicago: University of Chicago Press.

Cassidy DC (1985) Meterology in Mannheim: The Palatine Meteorological Society, 1780-1795. Sudhoffs Archiv 69(1): 8-25.

Christensen C (1997) The innovator's dilemma: When new technologies cause great firms to fail. Boston: Harvard Business School Press.

Collins H (1985) Changing order: Replication and induction in scientific practice. London: Sage.

Comfort N (2003) The tangled field: Barbara McClintock's search for the patterns of genetic control. Cambridge: Harvard University Press.

Cook HJ (2007) Matters of exchange: Commerce, medicine and science in the Dutch Golden Age. New Haven: Yale University Press.

Daston L (1991) The ideal and the reality of the Republic of Letters in the Enlightenment. Science in Context 4(2): 367-86.

Daston L and Galison P (2008) Scientific coordination as ethos and epistemology. In: Helmar Schramm et al. (eds) Instruments in art and science: On the architectonics of cultural boundaries in the $17^{\text {th }}$ century. Berlin: Walter de Gruyter, pp. 296-333.

David P (2005) From keeping 'nature's secrets' to the institutionalization of 'open science.' In: Ghosh R (ed) CODE: Collaborative ownership and the digital economy. Cambridge: MIT Press, pp. 85-108

Davis NZ (1997) Women on the margins: Three seventeenth-century lives. Cambridge: Belknap.

Deleuze G and Guattari F (2004) A thousand plateaus: Capitalism and schizophrenia 2. London: Continuum.

Duque RB et al. (2005) Collaboration paradox: Scientific productivity, the Internet, and problems of research in developing areas. Social Studies of Science 35(5): 755-785.

Erdős Number Project (2014). Available at: www.oakland.edu/enp (accessed August 20, 2014). 
Ferrary M and Granovetter M (2009) The role of venture capital firms in Silicon Valley's complex innovation network. Economy and Society 38 (May): 326-359.

Findlen P and Marcus H (2017) The breakdown of Galileo's Roman network: Crisis and community, ca. 1633. Social Studies of Science.

Fortun K (2001) Advocacy after Bhopal: Environmentalism, disasters, and new global orders. Chicago: University of Chicago Press.

Foucault M (1970) The order of things. London: Tavistock.

Fuller S (1991) Disciplinary boundaries and the rhetoric of the social sciences. Poetics Today 12(2): 301-325.

Galison P (1987) How experiments end. Chicago: University of Chicago Press. Gieryn TF (1999) Cultural boundaries of science: Credibility on the line. Chicago: University of Chicago Press.

Gogoley YuA and Gan MA (2007) The work of the S. I. Vavilov State Optical Institute in the creation of space objectives. Journal of Optical Technology 74(10): 3-6.

Goldgar A (1995) Impolite learning: Conduct and community in the Republic of Letters, 1680-1750. New Haven: Yale University Press.

Goodman D (1996) The Republic of Letters: A cultural history of the French Enlightenment. Ithaca: Cornell University Press.

Gordin M (2012) The pseudoscience wars: Immanuel Velikovsky and the birth of the modern fringe. Chicago: University of Chicago Press.

Gordin M (2015) Scientific Babel: How science was done before and after global English. Chicago: University of Chicago Press.

Grafton A (2009) A sketch map of a lost continent: The Republic of Letters. Republic of Letters 1(1), available at: http://rofl.stanford.edu/node/34, consulted February $28,2012$.

Graham L and Dezhina I (2008) Science in the new Russia: Crisis, aid, reform. Bloomington: Indiana University Press.

Groys B (1992) The total art of Stalinism: Avant-Garde, aesthetic dictatorship, and beyond. London: Verso.

Habermas J (1991) The structural transformation of the public sphere: An inquiry into a category of bourgeois society. Cambridge: MIT Press. 
Harris SJ (1996) Confession-building, long-distance networks, and the organization of Jesuit science. Early Science and Medicine 1(3): 287-318.

Hayden C (2003) When nature goes public: The making and unmaking of bioprospecting in Mexico. Princeton: Princeton University Press.

Hecht G (ed) (2011) Entangled geographies: Empire and technopolitics in the global Cold War. Cambridge: MIT Press.

Herran N, Boudia S and S Turchetti (eds) (2012) Transnational history and the history of science. special issue of British Journal of the History of Science 45(3).

Huigen S et al. (2010 The Dutch trading companies as knowledge networks. Leiden: Brill.

Jasanoff S and Martello ML (eds) (2004) Earthly politics: Local and global in environmental governance. Cambridge: MIT Press.

Josephson PR (1997) New Atlantis revisited: Akademgorodok, the Siberian city of science. Princeton: Princeton University Press.

Keller EF (1983) A feeling for the organism: The life and work of Barbara McClintock. New Haven: W. H. Freeman.

Kevles D (1971) 'Into hostile political camps:' The reorganization of international science in World War I. Isis 62(1): 47-60.

Klemun, M (2012) 'National consensus' as culture and practice. In: Ash M and J Surman (eds) The nationalization of scientific knowledge in the Habsburg Empire 18481918. London: Palgrave Macmillan, pp. 83-101.

Knell, S (2007) The sustainability of geological mapmaking: The case of the Geological Survey of Great Britain. Earth Sciences History 26(1): 13-29.

Knowles MD (1958) Presidential address: Great historical enterprises I. The Bollandists. Transactions of the Royal Historical Society 8: 147-66.

Knowles Middleton WE (1971) The experimenters: A study of the Accademia del Cimento. Baltimore: Johns Hopkins University Press.

Kojevnikov A (2002) The Great War, the Russian Civil War, and the invention of big science. Science in Context 15(2): 239-275.

Krige J and Barth KH (eds) (2006) Global powerkKnowledge: Science and technology in international affairs. Osiris 21. 
Kuhn TS (1962) The Structure of scientific revolutions. Chicago: University of Chicago Press.

Lakoff A (2005) Pharmaceutical reason: Knowledge and value in global psychiatry. Cambridge: Cambridge University Press.

Lakoff A (2017) A fragile assemblage: Mutant bird flu and the limits of risk assessment. Social Studies of Science.

Lamont M and Molnar V (2002) The study of boundaries in the social science. Annual Review of Sociology 28: 167-195.

Lamy J (2007) Le bureau des longitudes. La gestion des instruments et les régimes de savoirs au XIXe siècle. Revue d'anthropologie des connaissances 1(2): 167188.

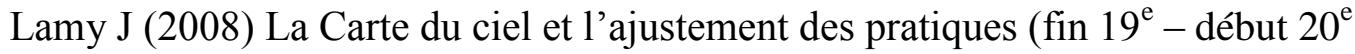
s.). In: Lamy J (ed) La Carte du ciel. Histoire et actualité d'un projet scientifique international. Les Ulis : EDP Sciences, pp. 45-67.

Latour B (1993) The pasteurization of France. Cambridge: Harvard University Press.

Latour B (1996) Aramis, or the love of technology. Cambridge: Harvard University Press.

Latour B (2005) Reassembling the social: An introduction to Actor-NetworkTheory. Oxford: Oxford University Press.

Latour B (2013) An inquiry into modes of existence. Cambridge: Harvard University Press.

Laudan L (1983) The demise of the demarcation problem. In: Cohen RS and Laudan L (eds) Physics, philosophy, and psychoanalysis: Essays in honor of Adolf Grünbaum. Dordrecht: Reidel, pp. 111-127.

Law J and Hassard J (eds) (1999) Actor Network Theory and after. Oxford: Blackwell.

Lee S and Bozeman B (2005) The Impact of research collaboration on scientific productivity Social Studies of Science 35(5): 673-702. 
Lipkowitz E (2014) Seized natural-history collections and the redefinition of scientific cosmopolitanism in the era of the French Revolution. British Journal for the History of Science 47(1): 15-41.

Lukács G (1962). Reflections on the cult of Stalin. The Marxist Archive, http://www.marxists.org/archive/lukacs/works/1962/stalin.htm.

Lux DS and Cook HJ (1998) Closed circles or open networks?: Communicating at a distance during the scientific revolution. History of Science 36: 179-211.

Macrakis, K (1993) Surviving the swastika: Scientific research in Nazi Germany. Oxford: Oxford University Press.

Malcolm N (ed) (1994) The correspondence of Thomas Hobbes. Oxford: The Clarendon Press.

Margocsy D (2010) 'Refer to folio and number:' Encyclopedias, the exchange of curiosities and practices of identification before Linnaeus. Journal of the History of Ideas 71(1): 63-89.

McClellan J, III (1985) Science reorganized: Scientific societies in the eighteenth century. New York: Columbia University Press.

Medvedev RA (1989) Let history judge: The origins and consequences of Stalinism. New York: Columbia University Press.

Mëhilli E (2014) Technology and the Cold War. In: Kalinovsky A and Daigle C (eds) The Routledge handbook of the Cold War. New York: Routledge, pp. 292-304.

Merton R (1968) Bureaucratic structure and personality. In: Merton R Social theory and social structure. New York: The Free Press, pp. 249-260.

Milgram S (1967) The small world problem. Psychology Today 2: 60-67

Miller DP (1998) The 'Hardwicke Circle': The whig Supremacy and its demise in the 18th-century Royal Society. Notes and records of the Royal Society of London 52(1): 73-91.

Mosley A (2007) Bearing the heavens: Tycho Brahe and the astronomical community of the late sixteenth century. Baltimore: Johns Hopkins University Press.

Mrazek R (2002) Engineers of happy land: Technology and nationalism in a colony. Princeton: Princeton University Press. 
Neri J (2011) The insect and the image: Visualizing nature in early modern Europe, 1500-1700. Minneapolis: University of Minnesota Press.

Newman MEJ (2001) The structure of scientific collaboration networks PNAS 98(2): 404-409.

Nyhan B, et al. (2014) Effective messages in vaccine promotion: A randomized trial. Pediatrics 133 (February): 835-842.

Ong A and Collier SJ (eds) 2005) Global assemblages: Technology, politics and ethics as anthropological problems. Oxford: Blackwell.

Owen-Smith J and Powell WW (2004) Knowledge networks as channels and conduits: The effects of spillovers in the Boston biotechnology community. Organization Science 15(1): 5-21.

Petryna A (2003) Life exposed; Biological citizens after Chernobyl. Princeton: Princeton University Press.

Petryna A (2009) When experiments travel: Clinical trials and the global search for human subject. Princeton: Princeton University Press.

Petryna A et al. (eds) (2006) Global pharmaceuticals: Ethics, markets, practices. Durham: Duke University Press.

Popper K (2005) The logic of scientific discovery. London: Routledge.

Powell WW et al. (2005) Network dynamics and field evolution: The growth of interorganizational collaboration in the life sciences. American Journal of Sociology 110(4): 1132-1205.

Pumfrey SP and Dawbam F (2004) Science and patronage in England, 15701625: A preliminary study. History of Science 42: 137-188.

Raj K (2007) Relocating modern science: Circulation and the construction of knowledge in South Asia and Europe, 1650-1900. New York: Macmillan.

Rankin W (2017) Zombie projects, negative networks, and multigenerational science: The temporality of the International Map of the World. Social Studies of Science.

Rheinberger HJ (1992) Experiment, difference, and writing: I. Tracing protein synthesis. Studies in History and Philosophy of Science A 23(2): 305-331.

Roberts L (ed) (2011) Centres and cycles of accumulation in and around the Netherlands during the early modern period. Berlin: LIT. 
Rusnock A (1999) Correspondence networks and the Royal Society British Journal for the History of Science 32(2): 155-169.

Schaffer S (2011) Easily cracked: Scientific instruments in states of disrepair. Isis 102(4): 706-717.

Simon Schaffer et al. (eds) (2009) The brokered world: Go-betweens and global intelligence, 1770-1820. Sagamore Beach: Science History Publications.

Schiebinger L (2004) Plants and empire: Colonial bioprospecting in the Atlantic world. Cambridge: Harvard University Press.

Schiebinger L and Swan C (eds) (2005) Colonial botany: Science, commerce, and politics in the early modern world. Philadelphia, University of Pennsylvania Press.

Secord J (2004) Knowledge in transit. Isis 95(4): 654-72.

Slezkine Yu (1991) The fall of Soviet ethnography. Current Anthropology 32(4): 476-484.

Smith L (2017) The missing, the martyred, and the disappeared: Global networks, technical intensification and the end of human rights genetics. Social Studies of Science.

Sooryamoorthy R (2014) Publication productivity and collaboration of researchers in South Africa: New empirical evidence. Scientometrics 98(1): 531-545.

Sooryamoorthy R and Shrum W (2007) Does the internet promote collaboration and productivity in the scientific community in South Africa? Journal of ComputerMediated Communication 12(2): 733-751.

Sörlin S (2008) Globalizing Linnaeus: Economic botany and travelling disciples. Tijdschrift voor Skandinavistiek 29(1-2): 117-143.

Star SL and Griesemer JR (1989) Institutional ecology, 'translations,' and boundary objects: Amateurs and professionals in Berkeley's Museum of Vertebrate Zoology, 1907-39. Social Studies of Science 19(3): 387-420.

Strathern M (1996) Cutting the network. Journal of the Royal Anthropological Institute 2(3): 517-535.

Thoren VE (1990) The lord of Uraniborg: A biography of Tycho Brahe. Cambridge: Cambridge University Press. 
Tresch J (2010) Even the tools will be free: Humboldt's romantic technologies. In: Aubin D et al. (eds) The heavens on Earth: Observatories and astronomy in nineteenth-century science and culture. Durham: Duke University Press, pp. 253-284.

Tresch J (2012) The romantic machine: Utopian science and technology after Napoleon. Chicago: University of Chicago Press.

Tsing A (2005) Friction: An ethnography of global connection. Princeton: Princeton University Press.

Vargha D (2014) Between East and West: Polio vaccination across the Iron Curtain in Cold War Hungary. Bulletin of the History of Medicine 88(2): 319-343.

Vedel JB and Irwin A (2017) 'This is what we got, what would you like?': Aligning and unaligning academic-industry relations. Social Studies of Science.

Waquet F (1989) Qu'est-ce que la République des Lettres? Essai de sémantique historique. Bibliothèque de l'École des Chartes 147(1): 473-502.

Waquet F (1998) Le Latin ou l'empire d'un signe. Paris: Albin Michel.

Windsor T (2014) Rekindling contact: Anglo-German academic exchange after the First World War. In: Ellis H and U Kirchberger (eds) Anglo-German ccholarly networks in the long nineteenth century. Leiden: Brill, pp. 212-231.

\section{Author biography}

Dániel Margócsy is university lecturer at the Department of History and Philosophy of Science, University of Cambridge. His work has focused on commercial networks in the early modern world, the history of the book, and the visual culture of the life sciences. He is the author of Commercial Visions: Science, Trade, and Visual Culture in the Dutch Golden Age (University of Chicago Press, 2014), and, with Márk Somos and Stephen N. Joffe, Reading Vesalius' Fabrica: Reception History and Worldwide Descriptive Census (Brill, forthcoming).

\section{Notes}

\footnotetext{
${ }^{1}$ Studies of networks, however, frequently categorize networks according to their vulnerabilities (Barabási, 2002b). While there is a substantial literature that applies complex network theory to scientific networks, such quantitative studies focus on establishing the nature of such networks, and less on their vulnerabilities (Barabási, 2002a; Ferrary and Granovetter, 2009; Newman, 2001; Owen-Smith and Powell, 2004; Powell et al., 2005).
} 


\footnotetext{
${ }^{2}$ The obvious exception is Ulisse Aldrovandi, whose will went into great length specifying how his successors should continue his publication project. I thank Paula Findlen for this point.

${ }^{3}$ MS Uffenbach Folio 13, Staats- und Universitätsbibliothek Göttingen.

${ }^{4}$ For another long-term project, meteorology in Mannheim, which ended after 15 years of activity because of Napoleon's occupation of the area, see Cassidy (1985).

${ }^{5}$ Johann Philip Breyne to Peter Collinson, 12 November, 1747, Forschungsbibliothek Gotha Chart A 873. On death in patronage networks, see Pumfrey (2004).
} 